\title{
Thiocyanate concentration in saliva of cystic fibrosis patients
}

\author{
Lukasz Minarowski ${ }^{1}$, Dorota Sands², Alina Minarowska ${ }^{3}$, Alicja Karwowska ${ }^{4}$, \\ Anetta Sulewska ${ }^{5}$, Marek Gacko ${ }^{6}$, Elżbieta Chyczewska ${ }^{1}$
}

Departments of: ${ }^{1}$ Lung Diseases and Tuberculosis, ${ }^{4}$ Instrumental Analysis, ${ }^{5}$ Clinical Molecular Biology and ${ }^{6}$ Vasal Surgery, Medical University of Bialystok, Poland

${ }^{2}$ Department of Pediatrics, Mother and Child Research Institute, Warsaw, Poland

33rd Department of Children's Diseases, Medical University in Bialystok, Poland

\begin{abstract}
Thiocyanates (SCN-) are ubiquitous in nature. There are indispensable part of host defense system that act as a substrate for lactoperoxidase (LPO). In our study we present initial data on SCN- concentration in saliva of CF patients in comparison to healthy non-smokers and healthy smokers. $5 \mathrm{ml}$ of saliva was collected from each subject to a sterile tube and thiocyanate concentration was measured in each sample. The results of the measurements are presented on Fig. 1. Mean concentration of $\mathrm{SCN}^{-}$in saliva of CF patients was $0.031 \pm 0.0052 \mathrm{~g} / \mathrm{l}$, in healthy non-smokers $0.039 \pm 0.0048 \mathrm{~g} / 1$ and in healthy smokers 0.048 $\pm 0.0161 \mathrm{~g} / \mathrm{l}$. The differences between each group were statistically significant. Studies on larger group of patients and probably on different material (BALF or induced sputum) should present interesting data complementing the in vitro studies.
\end{abstract}

Key words: Cystic fibrosis - Thiocyanate - Saliva

Thiocyanates $\left(\mathrm{SCN}^{-}\right)$are ubiquitous in nature. There are indispensable part of host defense system that act as a substrate for lactoperoxidase (LPO). LPO oxidize airway surface liquid $\mathrm{SCN}^{-}$thereby generating antimicrobial agent hypothiocyanite $\left(\mathrm{OSCN}^{-}\right)$[1-3]. The OSCNformation is believed to be necessary for elimination of bacteria from airway mucosal surfaces [4]. Recently publications report on impairment of this novel host defense system in cystic fibrosis patients. In a study on human and rat airway epithelia on cow tracheal explants Moskwa et al. [4] showed that CF epithelia failed to excrete $\mathrm{SCN}^{-}$and thus this system is

In our study we present initial data on $\mathrm{SCN}^{-}$concentration in saliva of CF patients in comparison to healthy non-smokers and healthy smokers. We decided to include the healthy smokers as an additional control group as it was previously shown that in this group $\mathrm{SCN}^{-}$levels in saliva are elevated [5].

Correspondence: Ł. Minarowski, Dept. of Lung Diseases and Tuberculosis, Medical University of Bialystok, Poland; tel.: (+4885) 7324149, fax.: (+4885) 7324149, e-mail: lukmin@mp.pl

\section{Materials and methods}

Patients. The study was conducted in three groups of patients CF patients, healthy non-smokers and healthy smokers. The groups were sex and age matched. In CF patients delF508 was present in $13(65 \%)$ allels. Other mutations were G542X - 2 allels $(10 \%)$, R553X - 2 allels (10\%), 2134delT - 1 allel (5\%), 3849+10kb C-T - 1 allel (5\%), one mutation was undefined.

Saliva samples. $5 \mathrm{ml}$ of saliva was collected from each subject to a sterile tube and the SCN- concentration was measured within $2 \mathrm{~h}$ after collection.

Thiocyanate designation. To $1 \mathrm{ml}$ of whole saliva $0.03 \mathrm{ml}$ of $2 \mathrm{M}$ $\mathrm{HCl}$ and $0.03 \mathrm{ml}$ of $5 \% \mathrm{FeCl}_{3}$ was added. Each sample was thoroughly mixed and estimated towards to control samples $\left(1 \mathrm{ml} \mathrm{H}_{2} \mathrm{O}\right.$, $0.03 \mathrm{ml}$ of $2 \mathrm{M} \mathrm{HCl}$ and $0.03 \mathrm{ml} 5 \% \mathrm{FeCl}_{3}$ ) at spectrophotometer at wave length of $\lambda=570 \mathrm{~nm}$.

Thiocyanate concentration was estimated according to calibration plot prepared using standard solutions of NH4SCN. The data from obtained from the calibration plot were calculated according to the equation:

$$
S C N^{-}[\mathrm{g} / \mathrm{l}]=\frac{[\text { concentration_from_the_plot }] \times\left[\mathrm{SCN}^{-} \text {molar_mass }=58 \mathrm{~g} / \mathrm{mol}\right]}{\left[\mathrm{NH}_{4} S \mathrm{SCN} \mathrm{CHolar}_{-} \text {mass }=76 \mathrm{~g} / \text { mol }^{\prime}\right]}
$$

Statistical analysis. The differences between mean were calculated using student t-test. 


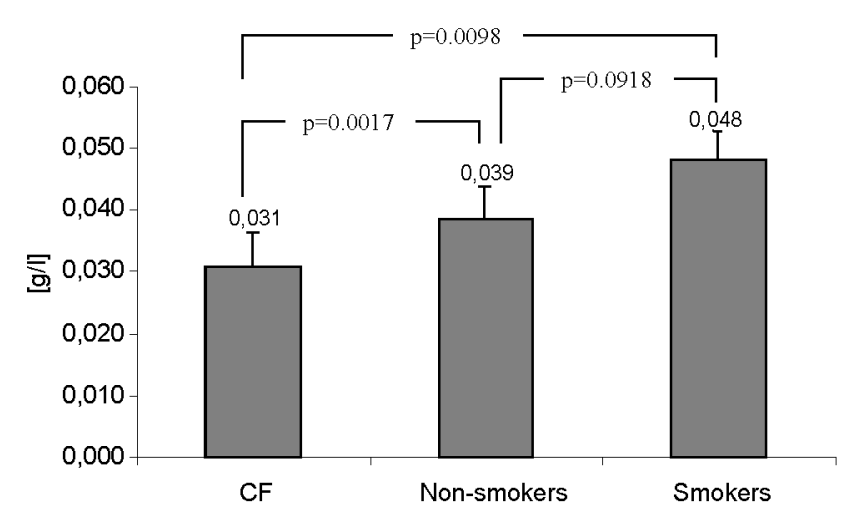

Fig. 1. The concentration of $\mathrm{SCN}^{-}$in saliva of $\mathrm{CF}$ patients, healthy non-smokers and healthy smokers.

\section{Results and discussion}

The results of the measurements are presented on Fig. 1. Mean concentration of SCN- in saliva of CF patients was $0.031 \pm 0.0052 \mathrm{~g} / \mathrm{l}$, in healthy non-smokers 0.039 $\pm 0.0048 \mathrm{~g} / \mathrm{l}$ and in healthy smokers $0.048 \pm 0.0161$ $\mathrm{g} / \mathrm{l}$. The differences between groups were statistically significant (Fig. 1) although the studied groups may be considered to small. The saliva was chosen as study material as it is one on the major sites of active LPO and is fairly easy to obtain [6].

The impaired LPO function and differed thiocyanate concentration was described by Azen [7] and this finding were confirmed in several recent studies [8]. Childers at al. reviewed a problem of impaired glutathione transport and its thiocyanate conjugates in cystic fibrosis patients [9]. $\mathrm{SCN}^{-}$ions were used as probe of $\mathrm{Cl}^{-}$channel pores since 1960s. It was shown that CFTR channel is permeable to thiocyanates $[9,10]$. In vivo studies are necessary to estimate exact lack of thiocyanates in cystic fibrosis patients in sites where LPO is active. Here we present preliminary results of the study on $\mathrm{SCN}^{-}$concentration in a small group of cystic fibrosis patients. Studies on larger group of patients and probably on different material
(BALF or induced sputum) should present interesting data complementing the in vitro studies.

Acknowledgements: This work was supported by research grant of Medical University of Bialystok no. 3-43784.

\section{References}

[ 1] Reiter N, Perraudin JP. Lactoperoxidase: Biological function. In: Peroxidases in Chemistry and Biology, vol I, eds. Everse J, Everse KE, Grisham MB. CRC Press. Boca Raton. 1991; pp. 143.

[2] Conner GE, Salathe M, Forteza R. Lactoperoxidase and hydrogen peroxidase metabolism in the airway. Am J Respir Crit Care Med. 2002;166:S57-S61.

[3] Weuffen W, Bergman H, Blohm H, Bohland H, Hiepe Th, Schonfeld P. Thiocyanate - a biological active ion of veterinary and medical relevance. Berl Munch Tierarztl Wschr. 2003;116:144-156.

[ 4] Moskwa P, Lorentzen D, Excoffon KJDA, Zabner J, MacCray Jr PB, Nauseef WM, Dupuy C, Banfi B. A novel host defense system of airways is defective in cystic fibrosis. Am J Respi Crit Care Med. 2007;175:174-183.

[ 5] Morabia A, Bernstein MS, Curtin F, Berode M. Validation of self-reported smoking status by simultaneous measurement of carbon monoxide and salivary thiocyanate. Prev Med. 2001; 32(1):82-8.

[6] Fragoso MA, Fernandez V, Forteza R, Randell SH, Salathe M, Conner GE. Transcellular thiocyanate transport by human airway epithelia. J Physiol. 2004;561:183-194.

[7] Azen EA. Salivary peroxidase activity and thiocyanate concentration in human subjects with genetic variants of salivary peroxidase. Arch Oral Biol. 1978;23:801-805.

[ 8] Gerson C, Sabater J, Scuri M, Torbati A, Coffey R, Abraham JW, Lauredo I, Forteza R, Wanner A, Salathe M, Abraham WM, Conner GE. The lactoperoxidase system functions in bacterial airway clearance. Am J Respir Cell Mol Biol. 2000; 22:665-671.

[9] Childers M, Eckel G, Himmel A, Caldwell J. A new model of cystic fibrosis pathology: lack of transport of glutathione and its thiocyanate conjugates. Med Hypoth. 2007;68:101-112.

[10] Linsdell P. Thiocyanate as a probe of the cystic fibrosis transmembrane conductance regulator chloride channel pore. Can J Physiol Pharmacol. 2001;79:573-579.

Submitted: 5 January, 2008 Accepted after reviews: 4 April, 2008 